\title{
Thailand characterization factors for human health damage of chemical substances in life cycle impact assessment
}

\author{
Chantima Rewlay-ngoen ${ }^{1}$, Seksan Papong ${ }^{2}$, Toshiaki Kubo ${ }^{3}$, Norihoro Itsubo ${ }^{4}$, \\ Pomthong Malakul ${ }^{5}$, Sate Sampattgul ${ }^{6, *}$ \\ ${ }^{1}$ Energy Engineering Program, Faculty of Engineering, Chiang Mai University, Chiang Mai, 50200 Thailand \\ ${ }^{2}$ National Metal and Materials Technology Center, National Science and Technology Development Agency, Pathumthani, 12120 Thailand \\ ${ }^{3}$ Mizuho Information \& Research Institute, Inc. 2-3 Kanda-Nishikicho, Chiyoda-ku, Tokyo 101-8443, Japan \\ ${ }^{4}$ Department of Environmental and Information Studies, Tokyo City University 3-3-1 Ushikubo-nishi, Tsuzuku Ward, Yokohama, Japan \\ ${ }^{5}$ The Petroleum and Petrochemical College, Chulalongkorn University, 10330 Bangkok \\ ${ }^{6}$ Department of Mechanical Engineering, Faculty of Engineering, Chiang Mai University, Chiang Mai, 50200 Thailand
}

\section{Email address:}

rchantima@gmail.com (C. Rewlay-ngoen), seksanp@mtec.or.th (S. Papong), toshiaki.kubo@mizuho-ir.co.jp (T. Kubo), itsubo-n@tcu.ac.jp (N. Itsubo), pomthong.m@chula.ac.th (P. Malakul), sate@eng.cmu.ac.th (S. Sampattagul)

\section{To cite this article:}

Chantima Rewlay-ngoen, Seksan Papong, Toshiaki Kubo, Norihoro Itsubo, Pomthong Malakul, Sate Sampattgul. Thailand Characterization Factors for Human Health and Biodiversity Damage of Chemical Substances in Life Cycle Impact Assessment. International Journal of American Journal of Environmental Protection. Vol. 2, No. 6, 2013, pp. 154-160. doi: 10.11648/j.ajep.20130206.16

\begin{abstract}
The environmental impact assessment for chemical substances on human health damage has been of significant interest sometime in the EU, USA, and Japan. In Thailand, such an environmental impact is now receiving more attention. The present study focuses on developing the damage factors of chemical substances on human health based on the multi-media box type fate and exposure model via IMPACT 2002, with the model adapted to Thailand. Human health damage factors are expressed in terms of disability-adjusted life year (DALY) per kg emission. The development method includes four steps: fate analysis, exposure analysis, potency, and severity analysis. This study derived new damage factors of 144 chemical substances that quantify the impact damage of an emission change on human health damage. It was found that the characterization factors for human health damage range from $7.34 \times 10^{-9}$ to $1.30 \times 10^{3}$ DALY per kg emitted. This work provides new information for damage factors on human health in Thailand based on the IMPACT 2002 model, modified for Thailand. Future research should include uncertainty analysis of the major relevant parameters, which could provide information on the reliability of the damage function.
\end{abstract}

Keywords: Human Toxicity, Impact Assessment, Endpoint Damage

\section{Introduction}

Life Cycle Assessment (LCA) is a tool used in assessing the environmental impacts of a product or service throughout its life cycle. It considers impacts from raw materials procurement, manufacturing process, transportation, use and disposal or, in other words, all the stages of a product's life from cradle-to-grave. LCA is covered by ISO 14040 Standard Series [1] which includes four steps: goal and scope definition, Life Cycle Inventory Analysis (LCI), Life Cycle Impact Assessment (LCIA) and interpretation. In the third phase, the aim of the LCIA is to converts the inventory data into potential environmental impacts [2]. It should be noted that LCIA classified into two approaches: midpoint and endpoint damage.

Traditional impact assessment methods (e.g. CML, EDIP, TRACI, and Eco-indicator 95) involve indicators somewhere between emission and endpoint in the environmental mechanism. The quantitative modeling is stopped before the end of the impact pathways and linked with LCI results in terms of "midpoint impact", e.g. global warming or acidification. Damage oriented methods (e.g. Eco-indicator 99, IMPACT 2002+, ReCiPe, and LIME) interpret the LCA results in a way that can be easily 
understood, by modeling the cause-effect chain up to the environmental damage on human health, ecosystems and natural resources [3]-[6].

Several LCIA methods have incorporated environmental damage from toxic substances [5], [7], [8]. The scope and methodologies of the toxic models have different development paths for each method. Some toxic model consider fate, exposure, and effect analysis on both human health and ecosystem impact such as CalTox model, while Eco-indicator 99, IMPACT 2002, and USEtox have developed damage factors for toxic chemicals by using damage analysis [9]-[16].
In addition, in Japan a LCIA method has been developed for evaluating environmental loading in the country, known as LIME [17]. The LIME framework includes toxic chemical damage with cancer and chronic disease as the endpoints integrated into the human health safeguard areas, as shown in Figure 1. Moreover, the LIME method used the IMPACT 2002 model that was developed by the Ecole Polytechnique Fédérale de Lausanne for calculating damage factors [18].

This paper aims to develop the characterization factors for human health damage of chemical substances by using the IMPACT 20002 model based on LIME method.

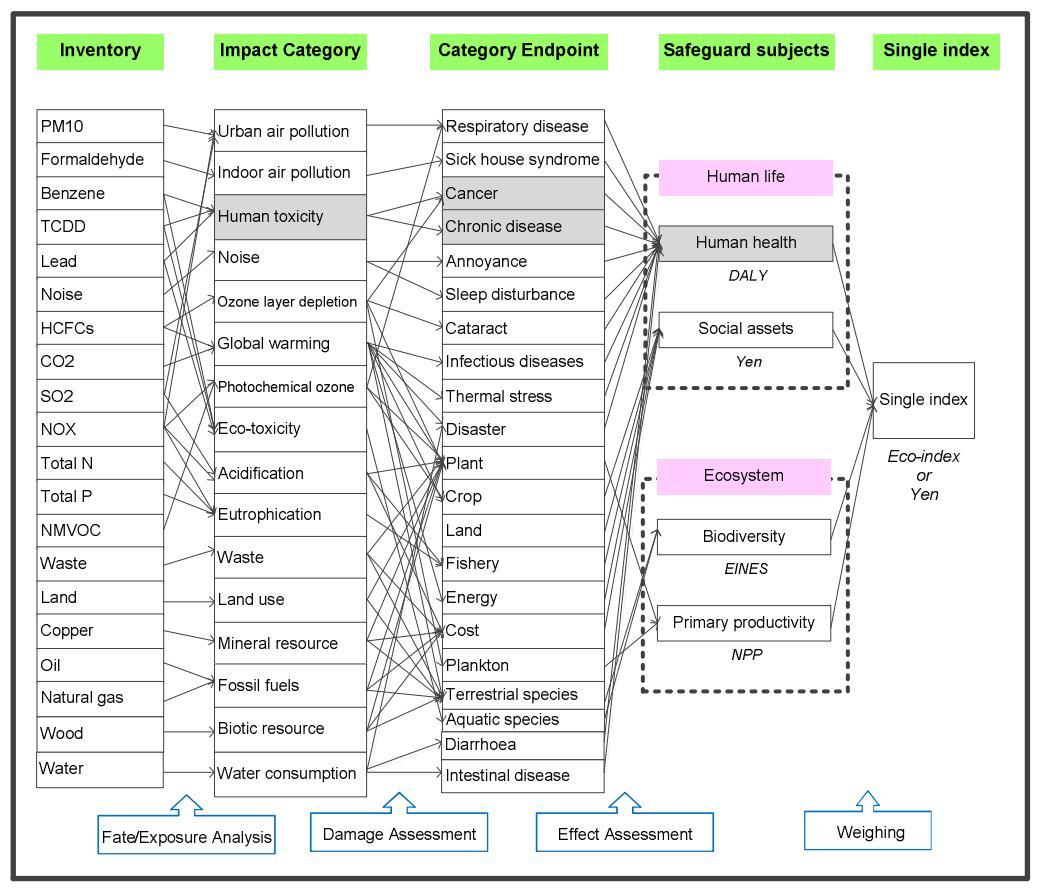

Figure 1. LCIA framework of LIME [18], [24]

\section{Methodology}

This study estimated the characterization factors for chemical toxicity effects on human health at endpoint level using the IMPACT 2002 model under conditions for Thailand and has adopted methodology based on the LIME method.

IMPACT2002 model respect a multimedia, multi-pathway, fate, exposure, effect, and damage steady-state model. In this model, concern the relationships between the movement of the chemical substance $i$ from compartment $m$ to compartment $n$ in the environment to humans through inhalation, ingestion, and skin contact. The result of fate and exposure analysis is to anticipate the Intake Fraction (IF) that can affect humans exposed to toxic substances. Potency is considered as the relationship between dose and response by converting the increased amount of exposure to the incident rate of cancer and other chronic diseases caused by various chemical hazards detected according to the Integrated Risk Information System (IRIS) of the U.S. Environmental Protection Agency
(US EPA) [19], database and Environmental Health Criteria Monographs (EHCS) of the International Programme on Chemical Safety (IPCS) [20]. The last factor, severity, is the damage function that will occur to each person, which can be measured as DALY (Disability Adjusted Life Year), in relation to the rate of incidence of cancer and chronic disease. The Characterization Factor (CF) of chemical substances on Human Health $\left(\mathrm{CF}_{\mathrm{HHi}}\right)$ in unit $(\mathrm{DALY} / \mathrm{kg})$ can be shown as in the equation (1).

$$
\begin{aligned}
C F_{H H_{i}} & =\sum_{i}\left\{\left(i F \cdot \operatorname{Pop}_{T H}\right) \cdot E F_{i}\right\} \\
= & \sum_{i}\left\{\left(i F \cdot \operatorname{Pop}_{T H}\right) \cdot\left(\beta_{i} \cdot D_{i}\right)\right\}
\end{aligned}
$$

The $I F$ depends on ingestion and inhalation exposure $(\mathrm{mg} / \mathrm{kg} / \mathrm{day})$. The Effect Factor (EF) is the relationship between potency and severity (case/(mg/day)). $\beta_{i}$ is toxicology potency (dose-response function) (risk of incidence/(mg/day)). $\quad D_{i} \quad$ is toxicology severity (DALY/incidence). $i$ is any chemical toxic substances. Pop $_{T H}$ is the population of Thailand based on the year 2012 (Applied from [18]). 
Table 1. Input parameters for intake fraction

\begin{tabular}{|c|c|c|c|c|}
\hline No. & Parameter & Unit & Amount & Reference \\
\hline 1 & Temperature & $\mathrm{K}$ & $3.00 \mathrm{E}+2$ & [25] \\
\hline 2 & Precipitation & $\mathrm{mm} / \mathrm{yr}$ & $1.49 \mathrm{E}+3$ & [26] \\
\hline 3 & $\begin{array}{l}\text { Precipitation } \\
\text { days during a } \\
\text { year }\end{array}$ & day/sec & $1.62 \mathrm{E}+2$ & [26] \\
\hline 4 & Evaporation & $\mathrm{mm} / \mathrm{yr}$ & $1.05 \mathrm{E}+3$ & $\begin{array}{l}\text { Estimated } 70 \% \\
\text { of precipitation }\end{array}$ \\
\hline 5 & Wind speed & $\mathrm{m} / \mathrm{sec}$ & $1.32 \mathrm{E}+0$ & [25] \\
\hline 6 & $\begin{array}{l}\text { Ocean current } \\
\text { speed }\end{array}$ & $\mathrm{m} / \mathrm{hr}$ & $1.06 \mathrm{E}+4$ & [26] \\
\hline 7 & $\begin{array}{l}\text { Surface area of } \\
\text { lake }\end{array}$ & $\mathrm{km}^{2}$ & $8.51 \mathrm{E}+3$ & [27] \\
\hline 8 & $\begin{array}{l}\text { Surface area of } \\
\text { river }\end{array}$ & $\mathrm{km}^{2}$ & $2.76 \mathrm{E}+3$ & [27] \\
\hline 9 & Watershed area & $\mathrm{km}^{2}$ & $3.76 \mathrm{E}+4$ & [27] \\
\hline 10 & Land area & $\mathrm{km}^{2}$ & $5.13 \mathrm{E}+5$ & [28] \\
\hline 11 & $\begin{array}{l}\text { Density of } \\
\text { aerosol }\end{array}$ & $\mathrm{mg} / \mathrm{m}^{3}$ & 7.70E-2 & [27] \\
\hline 12 & Pavement rate & $\%$ & 1.16 & [29] \\
\hline 13 & Pork production & ton & $7.55 \mathrm{E}+5$ & [30] \\
\hline 14 & Beef production & ton & $1.55 \mathrm{E}+6$ & [30] \\
\hline 15 & $\begin{array}{l}\text { Chicken } \\
\text { production }\end{array}$ & ton & $8.73 E+5$ & [30] \\
\hline 16 & Goat production & ton & $2.94 \mathrm{E}+4$ & [30] \\
\hline 17 & $\begin{array}{l}\text { Mutton } \\
\text { production }\end{array}$ & ton & $4.35 \mathrm{E}+3$ & [30] \\
\hline 18 & Egg production & ton & $5.00 \mathrm{E}+5$ & [30] \\
\hline 19 & Milk production & ton & $8.41 \mathrm{E}+5$ & [30] \\
\hline 20 & $\begin{array}{l}\text { Exposure } \\
\text { production }\end{array}$ & ton & $3.74 \mathrm{E}+8$ & [30] \\
\hline 21 & $\begin{array}{l}\text { Unexposure } \\
\text { production }\end{array}$ & ton & $3.76 \mathrm{E}+07$ & [30] \\
\hline 22 & Deep sea fishery & ton & $1.88 \mathrm{E}+05$ & $\begin{array}{c}\text { [30] based on } \\
\text { shrimp and } \\
\text { prawn }\end{array}$ \\
\hline 23 & Offshore fishery & ton & $8.75 \mathrm{E}+05$ & $\begin{array}{c}\text { [30] based on } \\
\text { pelagic and } \\
\text { demersal fish }\end{array}$ \\
\hline 24 & Sea culture & ton & $6.27 \mathrm{E}+05$ & $\begin{array}{l}\text { [30] based on } \\
\text { other fisheries } \\
\text { such as jelly } \\
\text { fish, shellfishes }\end{array}$ \\
\hline 25 & $\begin{array}{l}\text { Inland water } \\
\text { fishery }\end{array}$ & ton & $7.44 \mathrm{E}+04$ & [30] \\
\hline 26 & $\begin{array}{l}\text { Inland water } \\
\text { culture }\end{array}$ & ton & $4.17 \mathrm{E}+08$ & [30] \\
\hline 27 & $\begin{array}{l}\text { Culture fish of } \\
\text { inland water }\end{array}$ & ton & $1.99 \mathrm{E}+7$ & [30] \\
\hline 28 & $\begin{array}{l}\text { Ratio of surface } \\
\text { drinking water }\end{array}$ & - & 0.66 & [31] \\
\hline
\end{tabular}

The IMPACT 2002 model separated into three scales (1) direct surroundings (indoor or outdoor); (2) local scale (urban or non-urban); and (3) regional scale (which air cell, watershed or ocean zone is considered). This model can be adapted to Thailand conditions, which are change of watershed zone, coastal/ocean, and air zone models. For instance, the watershed zone modeling was adjusted by replacement with Thai databases include temperature, rainfall, land areas, $\mathrm{pH}$ of water, and number of eggs, pig, and goat. Coastal/ocean zone modeling has been adjusted by using data as Thai sea fish. Air zone was adopted by using
Thai databases such as dry deposition, Thai population, unexposure and exposure productions, and burnable area (as shown in Table 1). Toxicological potency is a quantitative measurement that determines the dose-response relationship and uses a slope factor based on risk per unit dose of a given effect for cancer. Crettaz et al. [22]-[23] proposed the cancer effects by using the related ED10. The toxicological severity average value is around 6.7 and 0.67 DALY per incidence for most cancer and chronic effects, respectively [22].

\section{Results and Discussion}

\subsection{Intake Fraction (IF) for Chemical Substances}

Figure 2 shows Thai intake factors for chemical substances. $I F$ concerns to air, water, and soil via inhalation and ingestion exposure to incident of cancer and chronic diseases for chemical substances range from 0 to $1.95 \times 10^{-3}$ $\mathrm{mg}$ intake/mg emitted. This implies that $0-1.95 \mathrm{~g}$ chemical substance is inhaled and ingested by Thai population per 1 $\mathrm{kg}$ of substance emitted. Two interesting points of $I F$ of chemical substances as following:

a) Ingestion exposure presented higher than inhalation exposure. With respect due to exposure human intake on the level separated, interconnected any location over the world, while ingestion only specific in Thailand.

b) Dioxin exposure in water was the highest value is 1.95 $\times 10^{-3} \mathrm{mg}$ intake $/ \mathrm{mg}$ emitted for both cancer and chronic diseases. The second value due to $\mathrm{Hg}$ is also exposure in water about $6.73 \times 10^{-4} \mathrm{mg}$ intake $/ \mathrm{mg}$ emitted for both cancer and chronic diseases.

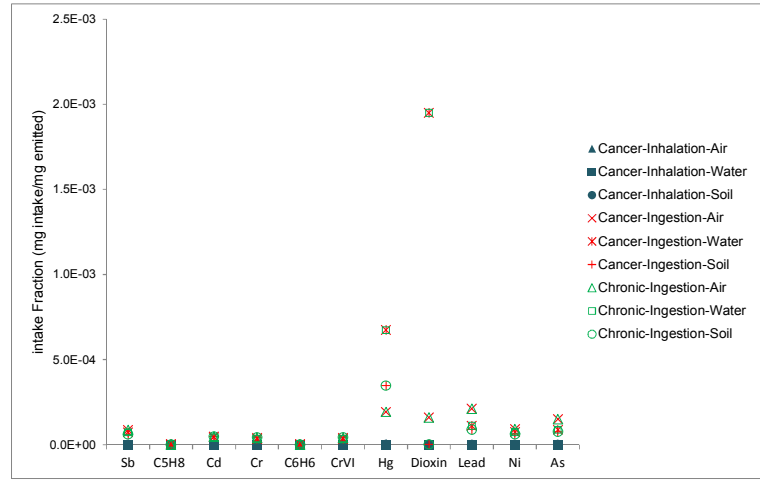

Figure 2. Intake factor of chemical substances

The IF of $\mathrm{C}_{6} \mathrm{H}_{6}$ via inhalation and ingestion was obtained in this study range from $1.84 \times 10^{-7}$ to $1.91 \times 10^{-6}$ and $1.32 \times$ $10^{-10}$ to $3.72 \times 10^{-6} \mathrm{mg}$ intake $/ \mathrm{mg}$ emitted, respectively. When comparing this result with a similar study by Humbert et al. [12], they reported the $\mathrm{IF}_{\mathrm{C} 6 \mathrm{H} 6}$ exposure via inhalation was $7.9 \times 10^{-6} \mathrm{mg}$ intake $/ \mathrm{mg}$ emitted, while exposure via ingestion was $1.2 \times 10^{-8} \mathrm{mg}$ intake $/ \mathrm{mg}$ emitted. This study is similar value to those obtained in previous studied.

\subsection{Characterization Factor of Chemical Substances}

The results of the CF of chemical substances in this study can be divided into emissions to atmosphere, surface water, 
and soil. It was found that 144 substances affect on human health expressed in term of DALY $/ \mathrm{kg}$ emitted. The variation in damage per $\mathrm{kg}$ emitted is large, up to thirteen orders of magnitude for human health damage (from $7.34 \times 10^{-9}$ $\mathrm{DALY} / \mathrm{kg}$ for permethrin up to $1.30 \times 10^{3} \mathrm{DALY} / \mathrm{kg}$ for dioxin). The damage factor on human health from the emission of toxin to atmosphere is between $3.13 \times 10^{-5}$ to
$1.06 \times 10^{2} \mathrm{DALY} / \mathrm{kg}$ emitted. The damage factor on human health from the spread of toxin to water is between $3.33 \mathrm{x}$ $10^{-5}$ to $1.30 \times 10^{3} \mathrm{DALY} / \mathrm{kg}$ emitted and the damage factor to human health from the discharge of toxin to soil is between $7.34 \times 10^{-9}$ to $1.26 \mathrm{DALY} / \mathrm{kg}$ emitted (the example of damage factors are shown in Table 2).

Table 2. Characterization factors of chemical substances on human health damage.

\begin{tabular}{|c|c|c|c|c|c|}
\hline No. & CAS number & Formula & Substances & Emission compartment & DALY/kg emitted \\
\hline \multirow[t]{3}{*}{1} & $1746-01-6$ & $\mathrm{C}_{12} \mathrm{H}_{4} \mathrm{Cl}_{4} \mathrm{O}_{2}$ & $\begin{array}{c}\text { Dioxin, } 2,3,7,8 \\
\text { Tetrachlorodibenzo-p- }\end{array}$ & Atmosphere & 106.54 \\
\hline & & & & Water & 1300.66 \\
\hline & & & & Soil & 1.26 \\
\hline \multirow[t]{3}{*}{2} & $7439-97-6$ & $\mathrm{Hg}$ & Mercury & Atmosphere & $2.01 \mathrm{E}-02$ \\
\hline & & & & Water & $7.00 \mathrm{E}-02$ \\
\hline & & & & Soil & $3.60 \mathrm{E}-02$ \\
\hline \multirow[t]{3}{*}{3} & $10031-13-7$ & $\mathrm{As}_{2} \mathrm{O}_{4} \mathrm{~Pb}$ & lead(II)-arsenite & Atmosphere & $1.45 \mathrm{E}-02$ \\
\hline & & & & Water & $8.42 \mathrm{E}-03$ \\
\hline & & & & Soil & $7.36 \mathrm{E}-03$ \\
\hline \multirow[t]{3}{*}{4} & $1303-00-0$ & GaAs & Gallium arsenide & Atmosphere & $1.45 \mathrm{E}-02$ \\
\hline & & & & Water & $8.42 \mathrm{E}-03$ \\
\hline & & & & Soil & $7.36 \mathrm{E}-03$ \\
\hline \multirow[t]{3}{*}{5} & $87-86-5$ & $\mathrm{C}_{6} \mathrm{HCl}_{5} \mathrm{O}$ & Pentachlorophenol & Atmosphere & $8.58 \mathrm{E}-03$ \\
\hline & & & & Water & $5.65 \mathrm{E}-02$ \\
\hline & & & & Soil & $1.24 \mathrm{E}-06$ \\
\hline \multirow[t]{3}{*}{6} & $1336-36-3$ & & 1,1'-Biphenyl, Chloro derivs & Atmosphere & $6.95 \mathrm{E}-03$ \\
\hline & & & & Water & $6.33 \mathrm{E}-01$ \\
\hline & & & & Soil & $1.12 \mathrm{E}-04$ \\
\hline \multirow[t]{3}{*}{7} & & & Nickel and compounds & Atmosphere & $4.05 \mathrm{E}-03-1.20 \mathrm{E}-05$ \\
\hline & & & & Water & $3.18 \mathrm{E}-03-5.63 \mathrm{E}-05$ \\
\hline & & & & Soil & $2.72 \mathrm{E}-03-4.82 \mathrm{E}-05$ \\
\hline \multirow[t]{3}{*}{8} & & & Arsenic and compounds & Atmosphere & $3.37 \mathrm{E}-03-7.78 \mathrm{E}-04$ \\
\hline & & & & Water & $1.60 \mathrm{E}-03-4.53 \mathrm{E}-04$ \\
\hline & & & & Soil & $1.39 \mathrm{E}-03-3.96 \mathrm{E}-04$ \\
\hline \multirow[t]{3}{*}{9} & & & Lead and compounds & Atmosphere & $1.09 \mathrm{E}-03-3.63 \mathrm{E}-04$ \\
\hline & & & & Water & $5.76 \mathrm{E}-04-1.90 \mathrm{E}-04$ \\
\hline & & & & Soil & $4.59 \mathrm{E}-04-1.51 \mathrm{E}-04$ \\
\hline \multirow[t]{3}{*}{10} & & & Cadmium and compounds & Atmosphere & $9.71 \mathrm{E}-02-3.38 \mathrm{E}-03$ \\
\hline & & & & Water & $2.78 \mathrm{E}-03-3.33 \mathrm{E}-05$ \\
\hline & & & & Soil & $3.08 \mathrm{E}-03-3.69 \mathrm{E}-05$ \\
\hline \multirow[t]{3}{*}{11} & $7782-49-2$ & $\mathrm{Se}$ & Selenium & Atmosphere & $1.50 \mathrm{E}-03$ \\
\hline & & & & Water & $9.05 \mathrm{E}-04$ \\
\hline & & & & Soil & $5.61 \mathrm{E}-04$ \\
\hline \multirow[t]{3}{*}{12} & $7446-34-6$ & $\mathrm{SSe}$ & Sulfur selenide & Atmosphere & $1.10 \mathrm{E}-03$ \\
\hline & & & & Water & $6.59 \mathrm{E}-04$ \\
\hline & & & & Soil & $4.08 \mathrm{E}-04$ \\
\hline \multirow[t]{3}{*}{13} & $117-81-7$ & $\mathrm{C}_{24} \mathrm{H}_{38} \mathrm{O}_{4}$ & Phthalate, dioctyl- & Atmosphere & $9.42 \mathrm{E}-04$ \\
\hline & & & & Water & $1.54 \mathrm{E}-02$ \\
\hline & & & & Soil & $3.23 \mathrm{E}-06$ \\
\hline
\end{tabular}




\begin{tabular}{|c|c|c|c|c|c|}
\hline No. & CAS number & Formula & Substances & Emission compartment & DALY/kg emitted \\
\hline \multirow[t]{3}{*}{14} & $41198-08-7$ & $\mathrm{C}_{11} \mathrm{H}_{15} \mathrm{BrClO}_{3} \mathrm{PS}$ & Profenofos & Atmosphere & $8.29 \mathrm{E}-04$ \\
\hline & & & & Water & $1.42 \mathrm{E}-02$ \\
\hline & & & & Soil & $3.29 \mathrm{E}-07$ \\
\hline \multirow[t]{3}{*}{15} & $7440-36-0$ & $\mathrm{Sb}$ & Antimony & Atmosphere & $1.07 \mathrm{E}-03$ \\
\hline & & & & Water & $9.02 \mathrm{E}-04$ \\
\hline & & & & Soil & 7.67E-04 \\
\hline \multirow[t]{3}{*}{16} & $7440-41-7$ & $\mathrm{Be}$ & Beryllium & Atmosphere & $3.40 \mathrm{E}-03$ \\
\hline & & & & Water & $3.05 \mathrm{E}-03$ \\
\hline & & & & Soil & $2.88 \mathrm{E}-03$ \\
\hline \multirow[t]{3}{*}{17} & $52645-53-1$ & $\mathrm{C}_{21} \mathrm{H}_{20} \mathrm{C}_{12} \mathrm{O}_{3}$ & Permethrin & Atmosphere & $3.08 \mathrm{E}-04$ \\
\hline & & & & Water & 4.33E-03 \\
\hline & & & & Soil & 7.34E-09 \\
\hline \multirow[t]{3}{*}{18} & $1163-19-5$ & $\mathrm{C}_{12} \mathrm{Br}_{10} \mathrm{O}$ & Decabromophenyl ether & Atmosphere & $2.63 \mathrm{E}-04$ \\
\hline & & & & Water & $1.22 \mathrm{E}-03$ \\
\hline & & & & Soil & $1.25 \mathrm{E}-07$ \\
\hline \multirow[t]{3}{*}{19} & $1314-62-1$ & $\mathrm{O}_{5} \mathrm{~V}_{2}$ & Vanadium pentoxide & Atmosphere & $2.56 \mathrm{E}-04$ \\
\hline & & & & Water & $1.71 \mathrm{E}-04$ \\
\hline & & & & Soil & $1.29 \mathrm{E}-04$ \\
\hline \multirow[t]{3}{*}{20} & $15972-60-8$ & $\mathrm{C}_{14} \mathrm{H}_{20} \mathrm{ClNO}_{2}$ & Alachlor & Atmosphere & $6.54 \mathrm{E}-05$ \\
\hline & & & & Water & $2.05 \mathrm{E}-03$ \\
\hline & & & & Soil & 4.20E-07 \\
\hline \multirow[t]{3}{*}{21} & $33089-61-1$ & $\mathrm{C}_{19} \mathrm{H}_{23} \mathrm{~N}_{3}$ & Amitraz & Atmosphere & $4.90 \mathrm{E}-05$ \\
\hline & & & & Water & $9.74 \mathrm{E}-03$ \\
\hline & & & & Soil & 4.63E-07 \\
\hline \multirow[t]{3}{*}{22} & $55-38-9$ & $\mathrm{C}_{10} \mathrm{H}_{15} \mathrm{O}_{3} \mathrm{PS}_{2}$ & Fenthion & Atmosphere & $4.58 \mathrm{E}-05$ \\
\hline & & & & Water & $1.23 \mathrm{E}-03$ \\
\hline & & & & Soil & $6.12 \mathrm{E}-08$ \\
\hline \multirow[t]{3}{*}{23} & $103-23-1$ & $\mathrm{C}_{22} \mathrm{H}_{42} \mathrm{O}_{4}$ & Adipate, bis(2-ethylhexyl)- & Atmosphere & 4.04E-05 \\
\hline & & & & Water & $5.28 \mathrm{E}-04$ \\
\hline & & & & Soil & $9.02 \mathrm{E}-09$ \\
\hline \multirow[t]{3}{*}{24} & $40487-42-1$ & $\mathrm{C}_{13} \mathrm{H}_{19} \mathrm{~N}_{3} \mathrm{O}_{4}$ & Pendimethalin & Atmosphere & $3.82 \mathrm{E}-05$ \\
\hline & & & & Water & $1.04 \mathrm{E}-03$ \\
\hline & & & & Soil & 9.47E-08 \\
\hline \multirow[t]{3}{*}{25} & $2312-35-8$ & $\mathrm{C}_{19} \mathrm{H}_{26} \mathrm{O}_{4} \mathrm{~S}$ & Propargite & Atmosphere & $3.13 \mathrm{E}-05$ \\
\hline & & & & Water & $6.05 \mathrm{E}-04$ \\
\hline & & & & Soil & $1.04 \mathrm{E}-08$ \\
\hline
\end{tabular}

Dioxin $\left(\mathrm{Cl}_{2} \mathrm{H}_{4} \mathrm{Cl}_{4} \mathrm{O}_{2}\right)$ causes the largest number of life years lost per unit emission, followed by mercury. The damage on human health due to cancer and chronic dioxin exposure to water has dominant contribution compared to other emitted substances. CFs for dioxin is 6-13 orders of magnitude more than other substances due to this substance can deposited in the liver through ingestion of freshwater fish [32]-[33] and it is very popular in Thailand.

When comparing this results with a similar study by Kubo and Itsubo [18], they reported the $\mathrm{CF}_{\mathrm{Hg}}$ in Japan was range from $2.25 \times 10^{-4}$ to $4.42 \times 10^{-3} \mathrm{DALY} / \mathrm{kg}$ emitted (excluding cancer disease). This is lower than the value obtained in this study $\left(\mathrm{CF}_{\mathrm{Hg}}\right.$ of this study ranged from $2.01 \times 10^{-2}$ to $7.00 \mathrm{x}$ $10^{-2} \mathrm{DALY} / \mathrm{kg}$ emitted). The main difference was due to Kubo and Itsubo study excluded cancer disease in the analysis, whereas our study included this aspect. ReCiPe is one impact assessment method that developed the CF for human toxicity by using the USES-LCA model for calculating the $\mathrm{CF}$ on human health. The $\mathrm{CF}_{\mathrm{Hg}}$ based on $\mathrm{ReCiPe}$ method was range $6.6 \times 10^{-3}$ to $3.6 \times 10^{-1} \mathrm{DALY} / \mathrm{kg}$ emitted [34], which is similar range to the value obtained in this study. 


\section{Conclusion}

In this study, the IMPACT 2002 model was modified to be suitable for Thailand based on LIME method. The adapted model was used in calculating the damage factors of 144 substances for human health expressed in term of DALY per $\mathrm{kg}$ emitted to air, water and soil. The variation in damage factor is large up to thirteen orders of magnitude. Dioxin causes the largest number of life years lost per unit emission, followed by mercury. CF of dioxin is 6-13 orders of magnitude more than other emitted substances due to this substance can be denoted in the liver through ingestion freshwater fish and it is very popular in Thailand. For CF of mercury, when compared to the previous study conducted by Kubo and Itsubo, they reported the $\mathrm{CF}_{\mathrm{Hg}}$ in Japan was lower than the value obtained in this study due to Kubo and Itsubo studied excluded cancer disease in the analysis. However, in comparison with the $\mathrm{CF}_{\mathrm{Hg}}$ based on ReCiPe method, the value obtained in our study was similar range to the ReCiPe method. Further development, the uncertainty analysis for key relevant parameters could be providing helpful information on the reliability of the calculated damage functions.

\section{Acknowledgment}

The authors would like to express their sincere appreciation to Assoc. Prof. Dr. Norihiro Itsubo for suggestions on the Life Cycle Impact Assessment Method and Toshiaki Kubo for advice about the Chemical Substance Model. Appreciation and thanks to the Electricity Generating Authority of Thailand (EGAT) for providing data on coal-fired, and natural gas power plants, the National Science and Technology Development Agency (NSTDA), and the Graduate School, Chiang Mai University for the financial support.

\section{References}

[1] ISO (International Organization for Standardization). ISO 14040: Environmental management-life cycle assessment-principals and framework. (2006a).

[2] ISO. ISO 14044: Environmental management-life cycle assessment-requirements and guidelines. (2006b).

[3] Bare, J., Hofstetter, P., Pennington, D.W., and Udo de Haes, H.A. Midpoint versus endpoint: The sacrifices and benefits. Int. J. Life Cycle Assess 5(6), 319-326. 2000.

[4] Jolliet, O., Müller-Wenk, R., Bare, J., Brent, A., Goedkoop, M., Heijungs, R., Itsubo, N., Pefia, C., Pennington, D., Potting, J., Rebitzer, G., Stewart, M., Udo de Haes, H., and Weidema, B. The LCIA midpoint-damge framework of the UNEP/SETAC life cycle initiative. Int J LCA 9 (6), 394-404. 2004.

[5] Bare, J.C. Life cycle impact assessment research developments and needs. Clean Technologies and Environmental Policy 12(4), 341-351. 2010.

[6] European Commission, Joint Research Centre and Institute for Environmental and Sustainability. International Reference Life Reference Life Cycle Data System (ILCD) handbook: Analysis of existing Environmental Impact Assessment methodologies for use in Life Cycle Assessment. 2010. Available online: http://europa.eu

[7] SETAC. Life Cycle Impact Assessment: Striving Towards Best Practice. Report by SETAC Europe Second Working Group on Life Cycle Impact Assessment. Edited by Udo de Haes, Finnveden, Goedkoop, Hauschild, Hertwich, Hofste. 2002 .

[8] Pennington, D.W., Margni, M., Payet, J., and Jolliet, O. Risk and regulatory hazard-based toxicological effect indicators in life-cycle assessment (LCA). Human and Ecological Risk Assessment: An International Journal 12(3), 450-475. 2012.

[9] de Koning, A., Guinée, J.B., Pennington, D.W., Sleeswijk, A., Hauschild, M.Z., Molander, S., Nyström, B., Pant, R., Schowanek, D. Methods and typology report Part A. Inventory and classification of LCA characterization methods for assessing toxic releases. OMNIITOX Deliverable D11A. 2002.

[10] Jolliet, O., Margni, M., Charles, R., Humbert, S., Payet, J., Rebitzer, G. and Rosenbaum, R. IMPACT $2002^{+}$: A new life cycle impact assessment methodology. Int. J. Life Cycle Assess 8(6), 324-330. 2003.

[11] Rosenbaum, R.K., Margni, M., and Jolliet, O. A flexible matrix algebra framework for the multimedia multipathway modeling of emission to impacts. Environment International 33, 624-634. 2007.

[12] Humbert, S., Margni, M., Charles, R., Torres Salazar, O.M., QuirÓs, A.L., and Jolliet, O. Toxicity assessment of the main pesticides used in Costa Rica. Agriculture, Ecosystems and Environment, 118, 183-190. 2007.

[13] Hauschild, M.Z., Huijbregts, M.A.J., Jolliet, O., MacLeod, M., Margni, M., van de Meent,, Rosenbaum, R.K., and McKone, T.E. Building a model based on scientific consensus for life cycle impact assessment of chemicals: The search for harmony and parsimony. Environ. Sci. Technol. 42, 7032-7037. 2008.

[14] Henderson, A.D., Hauschild, M.Z., van de Meent, D., Huijbregts, M.A.J., Larsen, H.F., Margni, M., McKone, T.E., Payet, J., Rosenbaum, R.K., and Jolliet, O. USEtox fate and ecotoxicity factors for comparative assessment of toxic emissions in life cycle analysis: Sensitivity to key chemical properties. Int $\mathrm{J}$ Life Cycle Assess 16, 701-709. DOI 10.1007/s11367-011-0294-6. 2010.

[15] Rosenbaum, R.K., Bachmann, T.M., Gold, L.S., Huijbregts, M.A.J., Jolliet, O., Juraske, R., Koehler, A., Larsen, H.F., MacLeod, M., Manuele, M., McKone, T.E., Payet, J., Schuhmacher, M., van de Meent, D., and Hauschild, M.Z. USEtox-the UNEP-SETAC toxicity model: Recommended characterisation factors for human toxicity and freshwater ecotoxicity in life cycle impact assessment. Int J Life Cycle Assess. DOI 10.1007/s11367-008-0038-4. 2008.

[16] Rosenbaum, R.K., Huijbregts, M.A.J., Henderson, A.D., Margni, M., McKone, T.E., van de Meent, Hauschild, M.Z., Shaked, S., Li, D.S., Gold, L.S., and Jolliet, O. USEtox human exposure and toxicity factors for comparative assessment of toxic emissions in life cycle analysis: sensitivity to key chemical properties. Int J Life Cycle Assess 16, 710-727. DOI 10.1007/s11367-011-0316-4. 2010. 
[17] Itsubo, N., and Inaba, A. A new LCIA method: LIME has been completed. Int J LCA 8(5), 305. 2003.

[18] Kubo, T. and Itsubo, N. Development of damage functions on human health caused by heavy metals in LIME. The Seventh International Conference on EcoBalance Designing Our Future Society Using Systems Thinking, 14-16 November 2006, EPOCHAL TSUKUBA, Tsukuba, Japan. 2006.

[19] US EPA. Integrated Risk Information System (IRIS). the U.S. Environmental Protection Agency (US EPA). 2012. Available online: http://www.epa.gov/iris

[20] IPCS (International Programme on Chemical Safety). Environmental Health Criteria Monographs (EHCS). 2012. Available online: http://www.inchem.org/ehc.html

[21] The Office of Scientific Affairs Department of Toxic Substances Control California Environmental Protection Agency Sacramento. CalTOX ${ }^{\mathrm{TM}}$, A Multimedia Total Exposure Model for Hazardous-Waste Sites: Spreadsheet User's Guide, Version 1.5. 1994.

[22] Crettaz, P., Pennington, D., Rhomberg, L., Brand, B., Jolliet, O. Assessing human health response in life cycle assessment using ED10s and DALYs: Part 1- Cancer effects. Risk Analysis 22(5), 931-946. 2002

[23] Crettaz, P., Pennington, D.W., Tauxe, A., and Jolliet, O. Assessing human health response in life cycle assessment using ED10s and DALYs, Part 2: Non-cancer effects, Risk Analysis 22(5), 947-963. 2002.

[24] Andrae, A.S.G. Chapter 3: Environmental Life Cycle Assessment from a LIME Perspective. In: Global Life Cycle Impact Assessments of Material Shifts Global Life Cycle Impact Assessments of Material Shifts. Springer London, 23-58. 2010.
[25] TMD (Thai Meteorological Department). Climatological Data of Thailand for 30 Year Period (1971-2000). Meteorological Data Report No. 551.5-03-2003. ISBN: 974-9616-03-0. 2003.

[26] TMD. Average Temperature. 2012. Available online: http://www.tmd.go.th

[27] ONEP (Office of Natural Resource and Environmental Policy and Planning). Environmental Situation Report 2010. Office of Natural Resource and Environmental Policy and Planning, Ministry of Natural Resources and Environment. 2011. Available online: http://www.onep.go.th

[28] THAICID (Thai National Committee on Irrigation and Drainage). Thailand. 2012. Available online: http://www.rid.go.th/thaicid

[29] PCD (Pollution Control Department). Environmental Emergency Reporting. 2012. Available online: http://www.pcd.go.th

[30] OAE (Office of Agricultural Economics). Agricultural Statistics of Thailand 2011. Office of Agricultural Economics, Ministry of Agriculture and Cooperatives, Bangkok. 2011. Available online: http://www.oae.go.th

[31] WHO/UNICEF. Joint Monitoring programme for water supply and sanitation-estimates for the use of improved drinking-water sources, Thailand. 2012.

[32] WHO. Dioxin there effects on human health. 2010

[33] Mudgal. V., Madaan, N., Mudgal, A., Singh, R.B., and Mishra, S. Effect of toxic metals on human health. The open nutraceuticals (3), 94-99. 2010.

[34] Eco-invent, ReCiPe (H). 2013. 